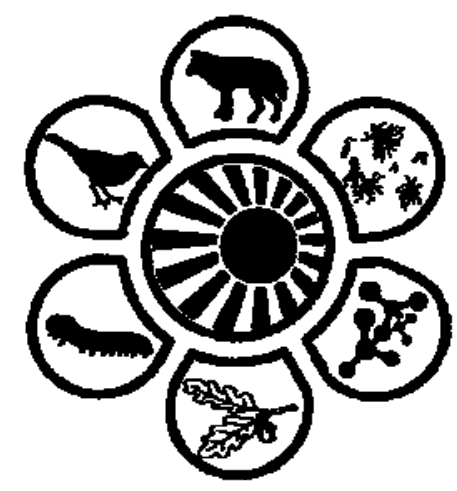

Вісник Дніпропетровського університету. Біологія, екологія.

Vìsnik Dnìpropetrovs'kogo unìversitetu. Seriâ Bìologiâ, ekologiâ

Visnyk of Dnipropetrovsk University. Biology, ecology.

Vìsn. Dnìpropetr. Unìv. Ser. Bìol. Ekol. 2015. 23(2), 203-209.

doi: $10.15421 / 011529$

ISSN 2310-0842 print

ISSN 2312-301X online

www.ecology.dp.ua

УДК 582.632.1:581.524

\title{
Особливості похідних березових молодняків у низькогір'ї Покуття (Українські Карпати)
}

\author{
С.Я. Мілевська
}

Інститут екологї Карпат НАН України, Львів, Україна

\begin{abstract}
Лісові ландшафти місцевого низькогір'я протягом останніх 3-5 століть зазнали глибокої антропогенної трансформації. Похідні молодняки тут займають до $25 \%$ загальної площі лісів. Проблема розвитку похідних деревостанів особливо актуальна для сучасної лісової типології в карпатському регіоні. Потребує відображення у типології динамічних тенденцій формування деревостанів, особливо змішаних молодняків. Мета нашого дослідження - пізнання структурних особливостей фітоценозів похідних березових молодняків у цьому районі. Об'єкт дослідження - молодняки I класу віку, що ростуть у басейні р. Лючка. Концептуальною основою нашого дослідження послужило сучасне динамічне розуміння типу лісу як послідовної серії лісових рослинних угруповань у межах однорідних умов місць росту. Застосовано методи еколого-флористичних досліджень школи Браун-Бланке в інтерпретації польської школи фітосоціології. У той же час до уваги брали синтаксономічні узагальнення українських учених. Фактичний матеріал - власні геоботанічні дослідження з фіксацією в рослинних угрупованнях переважної більшості видів. Обробляючи матеріал, головним чином до уваги брали види, що мають діагностичне значення для виділення синтаксонів рослинних угруповань. Молоді деревостани висотою 8-12 м та зімкненістю крон 70\% формують спільно дерева Betula pendula и B. pubescens. Досить чисельну домішку утворюють дерева Alnus incana, а також трапляються Fagus sylvatica, Populus tremula, Quercus robur, Padus avium. За домінантами такі фітоценози можна назвати сіровільховими березняками ожиново-осоково-орляковими - Betula pendula+Alnus incana-Rubus caesius-Carex brizoides+Pteridium aquilinum. Це багаті у флористичному відношенні рослинні угруповання. Вони містять щонайменше 12 деревних видів, 3 - чагарників, 4 - чагарничків та 89 - трав'янистих видів. Діагностичні види свідчать про приналежність таких угруповань до класу середньоєвропейських листяних лісів Querco-Fagetea. Водночас $є$ підстави вважати їх близькими до атлантичних кислих оліготрофних і мезотрофних листяних лісів класу Quercetea robori-petraeae. Однак 12 діагностичних видів підтверджують належність цих угруповань до порядку Fagetalia sylvaticae, який представляє європейські мезофітні широколисті ліси. На рівні союзів рослинних угруповань чіткої асоційованості не виявлено. Більшість діагностичних видів досліджених фітоценозів свідчить про близькість флористичної композиції до угруповань асоціації Potentillo albae-Quercetum, яка представляє світлі субконтинентальні діброви.
\end{abstract}

Ключові слова: рослинність; синтаксони; березняки; флора; Potentillo albae-Quercetum

\section{Features of secondary birch young stands in low mountain Pokuttya (Ukrainian Carpathian mts.)}

\author{
S.Y. Milevskaya \\ Institute of Ecology of the Carpathians of the National Academy of Sciences of Ukraine, Lviv, Ukraine
}

Forest landscapes of the region during the last 3-5 centuries undergone the profound anthropogenic transformation. Secondary young stands occupy $25 \%$ of the total forest area. The problem of derivatives is particularly relevant for the modern forest typology in the Carpathian region. It requires the reflection in its dynamic trends shaping the stands, especially mixed young stands. The aim of our study consisted in getting the knowledge of the structural features of the secondary phytocoenosis of birch young stands in this area.The object of the study was age class I saplings growing in the mountainous part of Pokuttya, particularly in the basin of the Lutshka River. The conceptual basis of our study is the modern dynamic vision that every forest type is a consecutive series of forest plant communities within each type of homogeneous growing conditions. We apply methods of ecological-floristic research of the Brown-Blanke school in the interpretation of the Polish school phytosociology. However we also take into account both syntaxonomy generalizations of the Ukrainian scientists. The actual

Інститут екологї Карпат НАН Украӥни, вул. Козельницька, 4, Львів, 79026, Украӥна

Institute of Ecology of the Carpathians of the National Academy of Sciences of Ukraine, Kozelnicka Str., 4, Lviv, 79026, Ukraine Tel.:+38-097-330-91-65,+38-032-270-74-30.E-mail:svetmil20@gmail.com,ecoinst@mail.lviv.ua 
material comprises the original geobotanical studies with fixation of the vast majority of species in plant communities. Mainly the species having diagnostic value to separate syntaxons were taken into account in the analytical processing. Young forest stands (with the height of $8-$ $12 \mathrm{~m}$ and crown cover of 70\%) together form the trees Betula pendula and B. pubescens. Fairly numerous admixture is formed by trees Alnus incana; besides, there are Fagus sylvatica, Populus tremula, Quercus robur, Padus avium. For dominants, they can be called "greyalder birch blackberry sedge bracken fern"-Betula pendula+Alnus incana-Rubus caesius-Carex brizoides+Pteridium aquilinum. It is rich in floristic composition of the plant communities. They contain at least 12 species of trees, 3 species of shrubs, 4 species of bushes and 89 species of herbs. Diagnostic species evidence the belonging of such groups to the class of Middle European broad-leaved forest QuercoFagetea. However, there is a reason to believe that they are close to the class of sour oligotrophic and mesotrophic Atlantic deciduous forests Quercetea robori-petraeae. 12 diagnostic species confirm belonging of these groups to the order Fagetalia sylvaticae represented by the European mesophytic deciduous forests. At the level of unions of plant communities no clear association was found. Most of the diagnostic species in phytocenoses under study indicate proximity of the floristic composition of the plants to association Potentillo albae-Quercetum which represents light subcontinental oak forest.

Keywords: vegetation; syntaxons; birch forests; flora; Potentillae albae-Quercetum

\section{Ветуп}

Березові ліси широко розповсюджені у бореальній зоні Європи, а також трапляються у горах у межах неморальної та субтропічної зон як азональні рослинні угруповання. Зокрема це піонерні або антропогенні фітоценози відновних сукцесій природної регенерації лісової рослинності, які вже досить повно досліджені у скандинавських країнах (Tømmervik, 2004; European forest types, 2006). Вони відіграють важливу роль у підтриманні біорізноманіття не лише на локальному, а i на регіональному рівні (Ellenberg, 1988; Bulakhov et al., 2003). Водночас має місце відновлення грунтового середовища. Молоді березняки доволі розповсюджені в горах Центральної та Східної Свропи. Однак вони ще потребують всебічного вивчення, як це зроблено у Родопах (Theodoropoulos, 2003). На жаль, у Карпатському регіоні відповідних досліджень не було проведено, а тому відсутні наукові публікації про ці лісові екосистеми. Досі не вивчено їх еколого-ценотичні особливості (Solomakha, 2008). Проте у новій класифікації типів лісу Європи (Barbati et al., 2011) вони належать до таких категорій та типів лісів:

1. Бореальні ліси:

1.1. Ялинові та ялиново-березові;

1.2. Соснові та сосново-березові.

2. Бореально-неморальні хвойні та мішані хвойно-широколистяні ліси:

2.5. Мішані сосново-березові ліси.

3. Альпійські ліси:

3.4. Гірські березові ліси.

4. Кислі дубові ліси:

4.2. Дубово-березові ліси.

11. Заболочені ліси:

11.4. Березові ліси на болотах.

13. Неприрічкові вільхові, березові та осикові ліси:

13.3. Гірські березові ліси;

13.4. Інші березові ліси.

Наші карпатські ліси, очевидно, близькі до вищенаведених категорій та типів лісу Свропи: особливо - до гірських березових лісів (3.4 та 13.3), а також до дубовоберезових лісів (4.2) та березових лісів на болотах (11.4).

Відповідно до середньоєвропейської фітосоціологічної класифікації класифікації школи Браун-Бланке, яка, зокрема, користується популярністю в Австрії, Німеччині, Польщі, Словаччині, Чехії тощо, молоді березові ліси у горах зараховано до союзу Sambuco-Salicion R.Tx. et Neum., 1950, що являє собою нітрофільні чагарниково- зарослеві угруповання початкових стадій сукцесії регенерації лісів на зрубах, лісових галявинах, луках i девастованих землях (Matuszkiewicz, 2001).

Унаслідок інтенсивного ведення лісового господарства сучасні ліси Карпатського регіону відзначаються глибоко зміненою віковою структурою. Станом на 2002 рік в Івано-Франківській області молодняки I класу віку займали майже 31 тис. га, а II класу - 80 тис. га, що загалом складає майже $25 \%$ загальної площі вкритих лісовою рослинністю земель (Korotkyy dovidnyk..., 2003). Таке становище характерне для всього лісового низькогір'я Карпат та, зокрема, для Покутського низькогір'я, лісові ландшафти якого зазнали упродовж 3-5 останніх століть глибокої антропогенної трансформації (Milevskaya, 2013).

Молоді ліси, які виникли внаслідок природного заростання зрубів і колишніх покинутих агрокультурних угідь, - це специфічні похідні динамічні природні утворення, що «належать до одного і того самого флористичного, екологічного та історико-генезисного комплексу», що й корінні типи лісу (Holubets, 2007). Такі вторинні екосистеми відзначаються зміненим екологічним потенціалом, який потребує комплексного екологоекономічного оцінювання. Водночас це породжує проблеми ефективності господарського використання таких вторинних екосистем, які ще мають знайти своє місце у лісовій типології (Holubets, 2003).

Проблема розвитку похідних деревостанів особливо актуальна в геоботаніці (Aleksandrova, 1964), а також важлива для сучасної лісової типології у Карпатському регіоні. Відображення у ній потребують динамічні тенденції формування деревостанів, особливо мішаних молодняків. Це необхідно зробити на основі класичного бачення природи типів лісу (Pohrebnyak, 1955), оскільки кожен тип лісу - це послідовна зміна лісових рослинних угруповань у межах кожного типу однорідних умов місцезростання. Саме тому мета нашого дослідження охарактеризувати структурні особливості фітоценозів похідних березових молодняків у горах Покуття.

\section{Матеріал і методи досліджень}

Концептуальною основою досліджень було застосування методів еколого-флористичної класифікації БраунБланке (Abduloyeva and Solomakha, 2011) в інтерпретації польської школи фітосоціології (Matuszkiewicz, 2001). Водночас до уваги брали також синтаксономічні узагальнення українських учених (Solomakha, 2008). 
Об'єкт дослідження - молодняки I класу віку, що ростуть у гірській частині Покуття, зокрема, у басейні р. Лючка. Належать вони до Березівського лісництва ДП «Кутське лісове господарство» (Мілевська, 2013). Це геоботанічний район покутсько-буковинських смереково-ялицево-букових лісів (Holubets, 2003). До висоти 600 м н. р. м. тут поширені грабово-букові ліси, головним типом лісу є волога грабова бучина 3 деревостанами IІа бонітету. Вище, у межах 600-900 м н. р. м., поширені майже чисті букові ліси, також I-Іа бонітету 3 домішкою явора, ясена, в'яза. Ще вище ростуть яворово-букові ліси середньої продуктивності.

Фактичний матеріал - власні геоботанічні дослідження на 13 дослідних ділянках, розташованих у різних частинах Березівського лісництва. Застосовано загальновідомі методи фітоценотичних досліджень (Mirkin and Rosenberg, 1978). Виконували фіксацію в рослинних угрупованнях переважної більшості видів, які визначали за допомогою українського визначника рослин (Prokudyn, 1987). Мохи визначали використовуючи таксономічні зображення 3 інтернет-ресурсу (Bryophytes: Mosses, Liverworts \& Hornworts). Головним чином для аналітичних опрацювань до уваги брали види, що мають діагностичне значення для виділення синтаксонів. Інформацію отримано 3 інтернет-ресурсу «Довідник назв рослин України» (Directory names of plants of Ukraine). Діагностуючи синтаксони рослинних угруповань, використали характерні (Ch.) і диференційні види (D.) класів (Cl.), порядків (O.), союзів (All.) та асоціацій (Ass.), а також - підсоюзів (SubAll.). Назви рослинних угруповань подано відповідно до середньо-європейської синтаксономічної номенклатури (Matuszkiewicz, 2001), а також додатково, для зручності порівняння, - за домінантами та субдомінантами, оскільки такий підхід в Україні найпоширеніший (Alekhin, 1951; Lavrenko and Korchagin, 1964; Valter, 1982).

Для уніфікованого подання результатів у таблиці застосовано традиційні підходи школи Браун-Бланке:

- вертикальні яруси фітоценозу (А - деревостан, В підріст, чагарники та чагарнички, $\mathrm{C}$ - трави, D - мохи та лишайники);

- клас постійності видів у множині досліджених фітоценозів (I - вид трапляється не більше ніж у 20\% фітоценозів, II - у 21-40\%, III - у 41-60\%, IV - у $61-$ $80 \%, \mathrm{~V}$ - вид трапляється у 81-100\% фітоценозів);

- проективне покриття ценопопуляціями поверхні обстеженої площі за кодами Matuszkiewicz (2001) («3»вид вкриває 1/4-1/2 (25-50\%) поверхні, «2»- вид вкриває менше 1/4 (25\%) поверхні, «1»- трапляється досить рясно, «+»-трапляється поодиноко).

\section{Результати та їх обговорення}

Узагальнені структурні особливості досліджених фітоценозів березових молодняків за найпоширенішими ценопопуляціями наведено у таблиці. Загалом такі фітоценози відзначаються значною гетерогенністю складових ценопопуляцій, які, однак, не мають значної переваги за проективним вкриттям.

Молоді деревостани висотою 8-12 м і зімкнутістю крон 70\% формують спільно дерева берез повислої
(Betula pendula Roth) та пухнастої (B. pubescens Ehrh.). Доволі численну домішку утворюють вільха сіра (Alnus incana (L.) Moench), ялина (Picea abies (L.) Karst.), ялиця біла (Abies alba Mill.), а також трапляються бук (Fagus sylvatica L.), осика (Populus tremula L.), дуб звичайний (Quercus robur L.), черемха звичайна (Padus avium Mill.).

Підріст рясний. Його формують молоді деревця B. pendula (проективне покриття 7\%), B. pubescens (проективне покриття 5\%). Трапляються поодинокі особини граба (Carpinus betulus L.), верби козячої (Salix caprea L.), клена-явора (Acer pseudoplatanus L.), а також Q. robur, P. abies та A. alba. Таким чином, у складі досліджених фітоценозів виявлено 12 деревних видів.

Чагарники трапляються зрідка (3 види): верба попеляста (Salix cinerea L.), верба вушката (Salix aurita L.), ліщина звичайна (Corylus avellana L.). Чагарнички утворюють фрагментарні зарості (4 види): ожина сиза (Rubus caesius L.) 3 домішкою ожини складчастої (R. plicatus Weihe et Nees), кістянки ( $R$. saxatilis L.) та малини (R. idaeus L.).

Трав'яний покрив щільний, зімкнений. Постійно представлені та утворюють фон 4 види: осока трясучковидна (Carex brizoides L.) - проективне покриття до 50\%, орляк звичайний (Pteridium aquilinum (L.) Kuhn.) - проективне покриття до 10\%, осока шариконосна (Carex pilulifera L.) - проективне покриття до 5\%, суховершки звичайні (Prunella vulgaris L.) - поширені доволі рясно. Часто трапляються (13 видів): безщитник жіночий (Athyrium filix-femina (L.) Roth), буквиця лікарська (Betonica officinalis L. s.1.), зеленчук жовтий (Galeobdolon luteum Huds.), костриця карпатська (Festuca carpatica F. Dietr.), купина кільчаста (Polygonatum verticillatum (L.) All.), любка дволиста (Platanthera bifolia (L.) Rich.), медова трава м'яка (Holcus mollis L.), ожика гайова (Luzula luzuloides (Lam.) Dandy et Wilmott), осока волосиста (Carex pilosa Scop.), підмаренник запашний (Galium odoratum (L.) Scop.), суниці лісові (Fragaria vesca L.), щитник австрійський (Dryopteris austriaca (Jacq.) Woynar ex Schinz et Thell.) та чоловічий (D. filix-mas (L.) Schott). Рідко трапляються, проте формують великі групи (6 видів): молінія голуба (Molinia caerulea (L.) Moench) проективне покриття 50\%, переліска багаторічна (Mercurialis perennis L.) - 15\%, зірочник ланцетовидний (Stellaria holostea L.) - 5\%, конвалія звичайна (Convallaria majalis L.) - до 5\%, біловус стиснутий (Nardus stricta L.) - 5\%, розхідник звичайний (Glechoma hederacea L.) проективне покриття 5\%. Зрідка зустрічаються такі трави (66 видів): анемона дібровна (Anemone nemorosa), апозерис смердючий (Aposeris foetida), астрагал солодколистий (Astragalus glycyphyllos), бедринець ломикаменевий (Pimpinella saxifraga), вербозілля гайове (Lysimachia nemorum), вербозілля звичайне (Lysimachia vulgaris), вербозілля лучне (Lysimachia nummularia), вероніка дібровна (Veronica chamaedrys), вороняче око звичайне (Paris quadrifolia), горошок лісовий (Vicia sylvatica), грястиця збірна (Dactylis glomerata), дзвоники розлогі (Campanula patula), дивина чорна (Verbascum nigrum), дрок красильний (Genista tinctoria), живокіст лікарський (Symphytum officinale), жовтозілля дібровне (Senecio nemorensis), звіробій звичайний (Hypericum perforatum), звіробій плямистий (H. maculatum), зеленчук жовтий (Galeobdolon luteum), зірочник гайовий (Stellaria 
nemorum), зозулинець шоломоносний (Orchis militaris), зубниця бульбиста (Dentaria bulbifera), зубниця залозиста (Dentaria glandulosa), квасениця звичайна (Oxalis acetosella), крем'яник гарний (Telekia speciosa), кремена біла (Petasites albus), кропива дводомна (Urtica dioica), кропива жалка (Urtica urens), куничник очеретяний (Calamagrostis arundinacea), купина багатоквіткова (Рolygonatum multiflorum), ліщина звичайна (Corylus avellana), люпин багатолистий (Lupinus polyphyllus), м'ята довголиста (Mentha longifolia), м'ята перцева (Mentha piperita), медунка темна (Pulmonaria obscura), мітлиця тонка (Agrostis tenuis), нечуйвітер волохатенькийй (Hieracium pilosella), ожика волосиста (Luzula pilosa), осока лісова (Carex sylvatica), осока пальчаста (Carex digitata), осока шершава (C. hirta), осот болотний (Cirsium palustre), пальчатокорінник плямистий (Dactylorhiza maculata), пахучка звичайна (Clinopodium vul- gare), перестріч лучний (Melampyrum pratense), перлівка поникла (Melica nutans), підмаренник білий (Galium album), підмаренник запашний (Galium odoratum), просянка розлога (Milium effusum), родовик лікарський (Sanguisorba officinalis), ситник розлогий (Juncus effusus), ситник скупчений (Juncus conglomeratus), ситник трироздільний (Juncus trifidus), сугайник австрійський (Doronicum austriacum), тирлич ваточниковий (Gentiana asclepiadea), трясучка середня (Briza media), фіалка рейхенбаха (Viola reichenbachiana), хвощ болотний (Equisetum palustre), цирцея альпійська (Circaea alpina), чемериця біла (Veratrum album), чина весняна (Lathyrus ver$n u s)$, чистець лісовий (Stachys sylvatica), шавлія залозиста (Salvia glutinosa), щавель горобиний (Rumex acetosella), яглиця звичайна (Aegopodium podagraria), ячмінь звичайний (Hordeum vulgare) тощо. Мохи трапляються невеликими групами (таблиця).

Таблиия

Структурні особливості досліджених фітоценозів похідних березових молодняків за переважаючими видами та їх діагностичне значення

\begin{tabular}{|c|c|c|c|}
\hline Яруси & Вид & $\begin{array}{c}\text { Клас постійності } \\
\text { (частота трапляння); } \\
\text { код проективного покриття }\end{array}$ & Діагностичне значення \\
\hline 1 & 2 & 3 & 4 \\
\hline A & Betula pendula & $\mathrm{V}(13) ; 3$ & DAll. Sambuco-Salicion \\
\hline $\mathrm{A}$ & Alnus incana & III (7); 1 & Немає даних \\
\hline $\mathrm{A}$ & Populus tremula & II (5); 2 & DAll. Sambuco-Salicion, \\
\hline A & Abies alba & II (3); + & $\begin{array}{l}\text { DAss. Luzulo luzuloidis-Fagetum, DAss. Abieti-Picetum } \\
\text { (montanum) }\end{array}$ \\
\hline A & Picea abies & II (10); 1 & ChO. Vaccinio-Piceetalia, ChAll. Piceion abietis \\
\hline $\mathrm{B}$ & Vaccinium myrtillus & $\mathrm{V}(13) ; 3$ & ChCl. Vaccinio-Piceetea \\
\hline $\mathrm{B}$ & Picea abies & V (13); 1 & ChO. Vaccinio-Piceetalia, ChAll. Piceion abietis \\
\hline $\mathrm{B}$ & Betula pubescens & IV (9); 2 & DAss. Sphagno girgensohnii-Piceetum \\
\hline $\mathrm{B}$ & B. pendula & IV $(10) ; 2$ & DAll. Sambuco-Salicion \\
\hline $\mathrm{B}$ & Sorbus aucuparia & III (8); 1 & DAll. Sambuco-Salicion \\
\hline B & Rubus caesius & III (7); 2 & Немає даних \\
\hline B & Rhodococcum vitis-idaea & II $(6) ; 2$ & Немає даних \\
\hline $\mathrm{B}$ & Abies alba & II (5); 1 & $\begin{array}{l}\text { DAss. Luzulo luzuloidis-Fagetum, DAss. Abieti-Picetum } \\
\text { (montanum) }\end{array}$ \\
\hline $\mathrm{B}$ & Rubus idaeus & II (3); 2 & ChCl. Epilobietea angustifolii \\
\hline $\mathrm{B}$ & Salix aurita & II (3);+ & ChCl. Alnetea glutinosae \\
\hline $\mathrm{B}$ & S. caprea & II (3);+ & ChAll. Sambuco-Salicion \\
\hline $\mathrm{C}$ & Pteridium aquilinum & III (8); 2 & $\begin{array}{l}\text { DAll. Pruno-Rubion fruticosi, DAss. (regionally) Betulo pendulae- } \\
\text { Quercetum roboris }\end{array}$ \\
\hline $\mathrm{C}$ & Carex brizoides & III (7); 2 & Немає даних \\
\hline $\mathrm{C}$ & Calamagrostis arundinacea & III (7); 1 & DAss. Potentillo albae-Quercetum \\
\hline $\mathrm{C}$ & Luzula pilosa & II (3); 3 & $\begin{array}{l}\text { DAss. Calamagrostio villosae-Pinetum, DAss. Luzulo pilosae- } \\
\text { Fagetum }\end{array}$ \\
\hline $\mathrm{C}$ & Lycopodium annotinum & II (5); 1 & $\begin{array}{l}\text { ChO. Vaccinio-Piceetalia, ChAss. Vaccinio uliginosi-Betuletum } \\
\text { pubescentis, ChAss. Abietetum polonicum, DAss. Luzulo pilosae- } \\
\text { Fagetum }\end{array}$ \\
\hline $\mathrm{C}$ & Dryopteris austriaca & II $(5) ;+$ & $\begin{array}{l}\text { DAll. Piceion abietis, ChAss. Vaccinio uliginosi-Betuletum pubes- } \\
\text { centis, ChAss. Abietetum polonicum }\end{array}$ \\
\hline $\mathrm{C}$ & Hieracium sylvularum & II (4);+ & Нема даних \\
\hline $\mathrm{C}$ & Homogyne alpina & II (4); + & $\begin{array}{l}\text { DAll. Nardion, ChAll. Piceion abietis, ChAss. Abieti-Picetum (mon- } \\
\text { tanum), DAss. Calamagrostio villosae-Pinetum }\end{array}$ \\
\hline $\mathrm{C}$ & Oxalis acetosella & II (4);+ & DSubAll. Alnenion glutinoso-incanae \\
\hline $\mathrm{C}$ & Athyrium filix-femina & II (3); 2 & $\begin{array}{l}\text { DSubAll. Vaccinio-Abietenion, DSubAll. Alnenion glutinoso- } \\
\text { incanae }\end{array}$ \\
\hline $\mathrm{C}$ & Calamagrostis villosa & II (3); 2 & $\begin{array}{l}\text { ChAll. Calamagrostion, DAss. Calamagrostio villosae-Pinetum, } \\
\text { DAss. Calamagrostio villosae-Piceetum }\end{array}$ \\
\hline $\mathrm{C}$ & Carex sylvatica & II (3); 2 & ChO. Fagetalia sylvaticae, \\
\hline $\mathrm{C}$ & Dryopteris filix-mas & II (3); 2 & Нема даних \\
\hline
\end{tabular}


Закінчення табл.

\begin{tabular}{|c|c|c|c|}
\hline 1 & 2 & 3 & 4 \\
\hline $\mathrm{D}$ & Sphagnum girgensohnii & IV (9); 2 & $\begin{array}{l}\text { ChAll. Piceion abietis, ChAss. (regionally) Calamagrostio villosae- } \\
\text { Pinetum, ChAss. Bazzanio-Piceetum, ChAss. (regionally) Sphagno } \\
\text { girgensohnii-Piceetum }\end{array}$ \\
\hline $\mathrm{D}$ & Pleurozium schreberi & IV (11); 2 & ChCl. Vaccinio-Piceetea \\
\hline $\mathrm{D}$ & Dicranum scoparium & IV (10); 2 & ChCl. Vaccinio-Piceetea \\
\hline $\mathrm{D}$ & Hylocomium splendens & III (7);2 & ChCl. Vaccinio-Piceetea, \\
\hline $\mathrm{D}$ & Polytrichastrum formosum & III $(6) ; 2$ & Немає даних \\
\hline $\mathrm{D}$ & Bazzania trilobata & II (4); 2 & $\begin{array}{l}\text { ChO. Vaccinio-Piceetalia, ChAss. (regionally) Querco-Piceetum, } \\
\text { ChAss. Bazzanio-Piceetum }\end{array}$ \\
\hline $\mathrm{D}$ & Polytrichum commune & II (3); 3 & ChAss. Bazzanio-Piceetum, DAss. Molinio (caeruleae)-Pinetum \\
\hline $\mathrm{D}$ & Dicranodontium denudatum & II (3); + & Немає даних \\
\hline $\mathrm{D}$ & Polytrichum juniperinum & II (3);+ & Немає даних \\
\hline $\mathrm{D}$ & Tetraphis pellucida & II (3); + & Немає даних \\
\hline A & Betula pubescens & IV (8); 1 & DAss. Sphagno girgensohnii-Piceetum \\
\hline $\mathrm{C}$ & Galeobdolon luteum & III (7); 1 & ChO. Fagetalia sylvaticae, DAll. Alliarion \\
\hline $\mathrm{C}$ & Fragaria vesca & III (7); + & $\begin{array}{l}\text { ChCl. Epilobietea angustifolii, DAss. Luzulo luzuloidis-Quercetum } \\
\text { petraeae }\end{array}$ \\
\hline $\mathrm{C}$ & Festuca carpatica & III (6); 1 & $\begin{array}{l}\text { ChAss. Festucetum carpaticae, DAss. Poo nemoralis-Arabidetum } \\
\text { alpinae, }\end{array}$ \\
\hline $\mathrm{C}$ & Holcus mollis & III (6); 1 & $\begin{array}{l}\text { ChCl. Quercetea robori-petraeae, DAll. Epilobion angustifolii, DAll. } \\
\text { Pruno-Rubion fruticosi, DAss. Molinio (caeruleae)-Quercetum } \\
\text { roboris }\end{array}$ \\
\hline $\mathrm{C}$ & Luzula luzuloides & III (6); + & $\begin{array}{l}\text { ChAll. Fagion sylvaticae, ChAll. Calamagrostion, hAss. Luzulo } \\
\text { luzuloidis-Fagetum }\end{array}$ \\
\hline $\mathrm{C}$ & Platanthera bifolia & III (6); + & Немає даних \\
\hline $\mathrm{C}$ & Polygonatum verticillatum & III $(6) ;+$ & ChCl. Betulo-Adenostyletea, \\
\hline $\mathrm{C}$ & Prunella vulgaris & III (7); 1 & ChCl. Molinio-Arrhenatheretea, DAss. Prunello-Plantaginetum, \\
\hline $\mathrm{C}$ & Carex pilulifera & III (6); 1 & $\begin{array}{l}\text { ChCl. Quercetea robori-petraeae, DAll. Epilobion angustifolii, DAss. } \\
\text { Luzulo pilosae-Fagetum }\end{array}$ \\
\hline $\mathrm{C}$ & Betonica officinalis & II (4);+ & DAss. Potentillo albae-Quercetum \\
\hline
\end{tabular}

За домінантами флористичної композиції можна назвати такі молоді лісові фітоценози: Betula pendula+ Alnus incana-Rubus caesius-Carex brizoides+Pteridium aquilinum. Тобто це сіровільхові березняки ожиновоосоково-орлякові.

За більшістю діагностичних видів такі угруповання виявляють належність до класу середньоєвропейських листяних лісів Querco-Fagetea (п'ять характерних видів: Melica nutans, Anemone nemorosa, Aegopodium podagraria, Carex digitata). Водночас є підстави вважати їх близькими також до атлантичних кислих оліготрофних i мезотрофних листяних лісів класу Quercetea roboripetraeae (три характерні види: Нурпит cupressiforme, Holcus mollis, Carex pilulifer). По одному характерному виду виявлено з класів Alnetea glutinosae - вільшини та вербняки, Betulo-adenostyletea - гірське різнотрав'я, Еріlobietea angustifolii - нітрофільні угруповання початкових стадій відновлення лісів на зрубах, Galio-Urticenea природні та антропогенні нітрофільні угруповання затінених місць, засмічених ділянок, узлісь та річкових заплав, Nardo-Callunetea - мокрих біловусових лук, Salicetea purpureae - заплавні тополеві вербняки, VaccinioPiceetea - бореальні хвойні ліси.

Такий спектр виявлених діагностичних видів рослинних угруповань, очевидно, цілком виправданий 3 огляду на процес трансформації рослинності в ході відновної сукцесії місцевих лісів, а також враховуючи локальне тимчасове заболочення зрубів та близький їх контакт із різними лісовими фітоценозами.

Інші 12 діагностичних видів (Paris quadrifolia, Galium odoratum, Aposeris foetida, Viola reichenbachiana, Polygonatum multiflorum, Lathyrus vernus, Carex sylvatica,
Dryopteris filix-mas, Mercurialis perennis, Pulmonaria obscura, Stachys sylvatica, Galeobdolon luteum, Epilobion angustifolii) характерні для порядку Fagetalia sylvaticae, що представляє європейські мезофітні широколистяні ліси.

Як і у випадку класів, виявлено також по одному характерному виду з інших порядків: Dactylis glomerata ChO. Arrhenatheretalia elatioris (пасовищні луки); Symphytum officinale - DO. Convolvuletalia sepium (прибережне різнотрав'я), Glechoma hederacea - ChO. Glechometalia hederaceae (нітрофільні угруповання лісових галявин i узлісь); Sanguisorba officinalis та Equisetum palustre - ChO. Molinietalia caeruleae (угруповання вологих сінокісних лук); Nardus stricta - ChO. Nardetalia - псянкових пустищ; Lysimachia nummularia та Carex hirta - ChO. Trifolio fragiferae-Agrostietalia stoloniferae (заплавні луки).

На рівні союзів рослинних угруповань більш-менш чіткої асоційованості не виявлено. Найбільш обгрунтованим було б зарахувати ці молоді лісові угруповання до союзу Epilobion angustifolii (різнотрав'я зрубів на бідних грунтах), про що свідчать три диференційні види - Carex pilulifera, Holcus mollis, Rumex acetosella. Інші три види (Dentaria bulbifera, D. glandulosa, Luzula luzuloides) характерні для союзу Fagion sylvaticae (букові ліси, бучини), ще три види (Betonica officinalis, Molinia caerulea, Pimpinella saxifraga) характерні для союзу Molinion caeruleae (молінієві однокісні луки). По два характерні види маємо і для угруповань інших союзів: дубовограбових лісів Carpinion betuli, заплавних вербових лісів Salicion albae, нітрофільних різнотравно-чагарникових заростей зрубів Sambuco-Salicion, чагарникових угруповань узлісь Pruno-Rubion fruticosi, високотравних лук i тінистого різнотрав'я Alliarion, Alopecurion pratensis, 
Calamagrostion. Водночас виявлено 4 диференційні види підсоюзу Alnenion glutinoso-incanae (заплавні вільхові ліси). Це Oxalis acetosella, Lysimachia vulgaris, Alnus incana, Athyrium filix-femina. Ще 5 видів є диференційними для групи асоціацій низовинних дібров на вологих і перезволожених грунтах: Molinia caerulea, Lysimachia vulgaris, Luzula pilosa, Pteridium aquilinum, Betula pubescens. Водночас 4 види (Luzula luzuloides, Betula pubescens, Lysimachia vulgaris, Molinia caerulea) є диференційними для групи асоціацій передгірських дібров на оглеєних грунтах, а інші 4 види (Quercus robur, Carex digitata, Viola reichenbachiana, Melica nutans) є диференційними для групи асоціацій мішаних борів.

Більшість видів (7: Pimpinella saxifraga, Calamagrostis arundinacea, Convallaria majalis, Astragalus glycyphyllos, Rubus saxatilis, Melampyrum pratense, Clinopodium vulgare, Betonica officinalis) дає підстави стверджувати про близькість флористичної композиції до угруповань асоціації Potentillo albae-Quercetum, яка представляє світлі субконтинентальні діброви.

\section{Висновки}

Похідні березові молодняки у низькогір'ї Покуття за домінантами можна назвати сіро-вільховими березняками ожиново-осоково-орляковими Betula pendula+Alnus incana-Rubus caesius-Carex brizoides +Pteridium aquilinum. Вони флористично багаті, містять щонайменше 12 деревних видів, 3 види чагарників, 4 види чагарничків та 89 видів трав.

За більшістю діагностичних видів такі угруповання виявляють належність до класу середньоєвропейських листяних лісів Querco-Fagetea. Водночас є підстави вважати їх близькими також до атлантичних кислих оліготрофних і мезотрофних листяних лісів класу Quercetea robori-petraeae. Інші 12 діагностичних видів підтверджують належність цих угруповань до порядку Fagetalia sylvaticae, що представляє європейські мезофітні широколистяні ліси.

На рівні союзів чіткої асоційованості не виявлено. Найбільш обгрунтованим було б зарахувати ці молоді лісові угруповання до союзів Epilobion angustifolii (різнотрав'я зрубів на бідних грунтах), Fagion sylvaticae (букові ліси, бучини) та Molinion caeruleae (молінієві однокісні луки). Водночас, за більшістю видів досліджені угруповання виявляють близькість флористичної композиції до угруповань асоціації Potentillo albae-Quercetum, яка представляє світлі субконтинентальні діброви.

Такий спектр виявлених синтаксонів, очевидно, цілком виправданий 3 огляду на процес трансформації рослинності в ході відновної сукцесії місцевих лісів, а також враховуючи локальне тимчасове заболочення зрубів та близький їх контакт із різними лісовими фітоценозами.

\section{Бібліографічні посилання}

Abduloyeva, O.S., Solomakha, V.A., 2011. Fitotsenolohiya [Phytocenology]. Fitosotsiotsentr, Kiev (in Ukrainian).
Alekhin, V.V., 1951. Rastitelnost SSSR v osnovnykh zonakh [Vegetation of the USSR in the primary terrestrial ecosystems]. Sovetskaya Nauka, Moscow (in Russian).

Aleksandrova, V.D., 1964. Izucheniye smen rastitelnogo pokrova [The study of changes of vegetation]. Polevaya geobotanika [Practicality geobotany]. Vol. 3. (ed. Lavrenko, E.M., Korchagin, A.A.). Nauka, Leningrad, 300-450 (in Russian).

Barbati, A., Corona, P., Marchetti, M., 2011. New european forest types. Complementary documentation. Annex to enquiry. State of forests and sustainable forest management in Europe 2011. United Nations, Geneva.

Bryophytes: Mosses, liverworts \& hornworts. Southern Illinois University Carbondale. Retrieved from URL: www.bryophytes.plant.siu.edu/index.html

Bulakhov, V.L., Emel'janov, I.G., Pakhomov, O.Y., 2003. Bioraznoobrazie kak funkcional'naja osnova jekosistem [Biodiversity as functional basis of ecosystems]. Vìsn. Dnìpropetr. Unìv. Ser. Bìol. Ekol. 11(1), 3-8.

Directory names of plants of Ukraine. Retrieved from URL: www.ekontsh.civicua.org/system.php

Ellenberg, H., 1988. Vegetation ecology of Central Europe. 4th ed. Cambridge University Press, Cambridge.

European forest types, 2006. Categories and types for sustainable forest management reporting and policy. EEA Technical report No 9.

Holubets', M. A., 2003. Suchasni problemy lisoznavstva, lisivnytstva ta lisovoho hospodarstva [Modern problems of forestry sciency and forest management]. Lisivnycha Akademiya Nauk Ukrayiny: Naukovi Pratsi 2, 20-26 (in Ukrainian).

Holubets', M., 2003. Heobotanichne rayonuvannya Ukrayins'kykh Karpat - osnova ratsional'noho pryrodokorystuvannya [Geobotanical zoning Ukrainian Carpathians - the basis of environmental management]. Pratsi Naukovoho tovarystva im. Shevchenka. Ekolohichnyy zbirnyk: Ekolohichni problemy Karpats'koho rehionu [Proceedings of the Shevchenko Scientific Society. Ecological Collection: Ecological Problems of Carpathian Region]. Shevchenko Scientific Society, Lviv, 12. 283-292 (in Ukrainian).

Holubets', M.A., 2007. Retrospektyva i perspektyva lisovoyi typolohiyi [Retrospective and perspective of forest typology]. Polli, L'viv (in Ukrainian).

Korotkyy dovidnyk lisovoho fondu Ukrayiny za materialamy obliku lisiv stanom na 1 sichnya 2003 roku, 2003 [Quick reference of forest inventory of Ukraine on the materials accounting as of January 1, 2003]. Irpin' (in Ukrainian).

Lavrenko, E.M. Korchagin, A.A. (ed.), 1964. Polevaya geobotanika [Practicality Geobotany], Nauka, Leningrad, 3 (in Russian).

Matuszkiewicz, J.M., 2001. Przewodnik do oznaczania zbiorowisk roślinnych Polski. Wydanie istotnie zmienione $\mathrm{w}$ stosunku do wydania z 1981. [Guide for the determination Polish plant communities. Edition significant change compared to the 1981 edition], PWN, Warszawa (in Polish).

Milevskaya, S.Y., 2013. Zminy struktury lisiv hirs'koyi chastyny baseynu richky Lyuchky uprodovzh 1967-2010 rokiv [Changes in the forests structure of the mountain part of Lyuchka river basin during 1967-2010 years]. Naukovyy visnyk. Natsional'nyy Lisotekhnichnyy Universytet Ukrayiny. 23(18), 22-27 (in Ukrainian).

Mirkin, B.M., Rosenberg, G.S., 1978. Phytocenology: Principles and methods. Nauka, Moscow (in Russian).

Pohrebnyak, P.S., 1955. Osnovy lesnoy tipologii [Fundamentals of forest typology]. Izdatelsvo AN USSR, Kiev (in Russian).

Prokudyn, Y.N. (ed.), 1987. Opredelitel vysshikh rasteny Ukrainy [Guide of higher plants of Ukraine]. Naukova Dumka, Kiev (in Russian). 
Solomakha, V.A., 2008. Syntaksonomiya roslynnosti Ukrayiny. Tretye nablyzhennya [Syntaxonomy of vegetation of Ukraine. The third approach]. Fitosotsiotsentr, Kyiv (in Ukrainian).

Theodoropoulos, K., Eleftheriadou, E., Athanasiadis, N., Tsiripidis, I., 2003. Phytosociological research of the pure Betula pendula forests in Greece: Rhodope mountain range (NE Greece). Annali di Botanica (Nuova Serie) 111, 75-90.
Tømmervik, H., Johansen, B., Tombre, I., Thannheiser, D., Høgda, K.A., Gaare, E., Wielgolaski, F.E., 2004. Vegetation changes in the Nordic Mountain Birch Forest: the influence of grazing and climate change. Arct. Antarct. Alp. Res. 36(3), 323-332.

Valter, G., 1982. Obshchaya geobotanika [General Geobotany]. Mir, Moscow (in Russian).

Надійшла до редколегї̈ 12.06.2015 